\title{
Comparing Turnover Drivers: Differences and Similarities in Two Economic Sectors
}

\author{
Charlotte Pietersen \\ Department of Business Management, \\ University of Limpopo, Turfloop Campus, Sovenga, 0727, Republic of South Africa \\ charlotte.pietersen@ul.ac.za \\ Olabanji Adegboyega Oni \\ Department of Business Management, \\ University of Limpopo, Turfloop Campus., Sovenga, 0727, Republic of South Africa \\ olabanji.oni@ul.ac.za
}

\author{
Doi:10.5901/mjss.2014.v5n7p148
}

\section{Abstract}

In this study employee turnover drivers in two organizations from different economic sectors are compared. A mixed method design, comprising of a questionnaire survey, semi-structured interviews and focus groups discussions, was used to collect data from two stratified sample of participants and key informants in a public and a private sector organization. Organizational documents were mined for secondary data on turnover rates. The results of the study show a high overall employee turnover rate in the public sector organization and an acceptable rate of turnover in the private sector organization. The difference in turnover rates is mainly attributed to the high turnover rate for younger employees in the public sector organization. The turnover rate for females in this organization is also exceptionally high. Job dissatisfaction in both organizations is attributed to poor compensation, better job offers elsewhere and a lack of promotional opportunities. Turnover in the public sector organization is also ascribed to poor working conditions, and to problems with supervision and interpersonal relationships. The costs and impact of job dissatisfaction on the productivity, efficiency and service delivery is more severe in the public sector organization. A number of human resource practices are recommended to manage employee retention.

Keywords: Employee turnover rates; turnover drivers; demographic factors, job satisfaction, job dissatisfaction, retention practices

\section{Introduction}

The retention of human resources is a matter of concern in Limpopo Province, one of the nine provinces in South Africa. The steady migration of a sizeable portion of the economically active population to more urbanized and economically viable areas in the country (mainly to the neighbouring Gauteng) creates a problem for businesses in the region (Oosthuizen \& Naidoo, 2004, Radebe, 2009). In general, organizations are unable to control the availability of lucrative alternative job options but the internal drivers of employee turnover can, to a large extent, be managed from within the walls of an organization (Allen, 2008).

To date no research has been conducted to compare the drivers of employee turnover in different economic sectors within a specific region of South Africa. The aim of the study is to offer a working example of the difference and similarities in employee turnover in a public and a private organization in Limpopo Province. The objectives of the study are to compare the turnover rates and drivers of dysfunctional employee turnover in the two organizations and, to recommend retention practices to manage employee turnover in the region.

\section{Literature Review}

\subsection{Dysfunctional employee turnover}

Employee turnover is the voluntary or involuntary movement of workers in and out of organizations (Choi, Musibau, Khalil \& Ebi, 2012). Voluntary turnover is the result of an employee's decision to seek alternative employment. Involuntary turnover is attributed to uncontrollable factors such as retirement, ill health or death, as well as to an employer's decision to discharge an employee. Voluntary turnover is far more prevalent than involuntary turnover (CIPD, 2011). Even so, both 
types of turnover could be dysfunctional for organizations. The organizational impact of employee turnover are usually assessed in terms the effect of the variable on an organization's bottom line, efficiency and service delivery (Chen, 2008; Waldman, Kelly, Arora \& Smith, 2004; Wright \& Kim, 2004). The management of dysfunctional employee turnover (voluntary well as involuntary turnover) therefore, continues to be a central concern for both public and private business enterprises (Choi \& Lee, 2011: 91).

\subsection{Employee turnover drivers}

The drivers of employee turnover are the factors that cause employee turnover (Allen, 2008). For the purpose of the present study turnover drivers are categorized into demographic factors, job satisfaction and job dissatisfaction.

\subsubsection{Demographic factors}

Demographic factors such as age, tenure, gender, and job position are associated with employee turnover (Schneider \& Vaught, 1993). It would appear that older, long-serving employees are much less inclined to look for greener pastures compared to younger employees (Kabungaidze, Mahlatshana \& Ngirande, 2013). There are also differences in the rate of turnover for males and females. In general, the turnover rate for female employees is higher than the rate for male employees (Nel, Van Dyk, Haasbroek, Schultz, Sono \& Werner, 2011). Lastly, there seems to be a relationship between job position and turnover. Employees in lower job positions are more inclined to leave than employees who occupy positions higher up in an organizational hierarchy (Kellough \& Haoran, 1993).

The employee turnover profile of an organization could be used to identify particular demographic factors within the organisation that drive employee turnover (Lynch \& Tuckey, 2008). The turnover profile could be established by calculating the annual overall employee turnover rate as well as turnover rates for different demographic groupings within an organization.

\subsubsection{Job satisfaction}

Job satisfaction has emerged as the most widely studied driver of employee turnover (Liu, Mitchell, Lee, Holtom \& Hinkin, 2012). The concept is defined as 'a positive or pleasurable affective response resulting from the appraisal of various facets of one's job' (Kasimati, 2011: 321). Herzberg and his co-workers use the term intrinsic motivators to refer to the dimensions/ facets of a job that are associated with high or low levels of job (Herzberg, Mausner \& Snyderman, 1959). These intrinsic motivators in the job content environment gratify employees' needs for achievement, competency, status, personal worth and self-realization. Job dimensions comprise of the nature of the work itself, recognition, responsibility, autonomy, challenging work, personal growth opportunities, and advancement. Low levels of satisfaction with intrinsic motivators could drive employees to resign from their jobs. For example, employees will leave when better growth opportunities and more challenging jobs are offered by other organizations (Walsh \& Taylor, 2007). On the other hand, intrinsic conditions of the job itself could motivate employees to higher levels of performance and to add value to their organizations.

It is generally assumed that private organizations are superior to public organizations. However, Rainey and Bozeman (2000) reviewed two decades of empirical research in which public and private organizations were compared. They concluded that empirical findings about the differences and similarities between public and private organizations are still inconclusive. It would appear that the same conclusion can be drawn with regard to differences and similarities when overall levels of job satisfaction as well as dimensions of job satisfaction in the two sectors.

Findings on the relationship between intrinsic motivators and employee turnover in the public and private sector are contradictory. Recent results of variance analysis done by Borges (2013) confirm previous research results and show that the overall job satisfaction of public officials are lower compared to the overall job satisfaction levels of private sector workers. In contrast to these findings Macklin, Smith and Dollard (2006) as well as Schneider and Vaught (1993) found that there is no difference in the overall job satisfaction of public sector employees and their counterparts in the private sector.

The same picture emerges when satisfaction dimensions are evaluated. Maidani's (1991) results show that employees in both sectors place a high value on intrinsic motivators. However, some researchers found that private sector employees are more motivated by intrinsic factors, such as challenge, responsibility and self-development than are public sector employees (Buelens \& Van den Broeck, 2007), while other studies (Kasimati, 2011; Sulaiman \& Ogunsina; 2011) provide evidence to the contrary. Blue collar workers in both sectors in Australia experience low levels of job 
satisfaction attributed to lack of a sense of mastery and control, and a lack of support (Macklin, et al., 2006).

\subsubsection{Job dissatisfaction}

According to Hertzberg (1968), job dissatisfaction drives employee turnover when employees have negative affective reactions to hygiene factors present in the job context environment. Hygiene factors are extrinsic to the job itself and include factors such as compensation, development/training and promotion opportunities, job security, working conditions, human resource policies, supervision, and interpersonal relations (Ito, 2003).

The results of a study by Wang, Yang and Wang (2012) confirm previous research findings that public sector employees have higher levels of overall job dissatisfaction compared to employees in the private sector. For the most part the same trend is apparent when employees' dissatisfaction with different hygiene factors is compared. Compared to private sector employees, public sector employees place a higher value on hygiene factors such as pay and job security (Maidani, 1991). They are more dissatisfied with compensation compared to their counterparts in the public sector (Borgia \& Blau, 1998; Gupta, 2011). Compensation, as well as working conditions and development opportunities, were found to contribute most to the job dissatisfaction and turnover of public service employees (Meier \& Hicklin, 2008; Miceli \& Mulve, 2000). They are also more dissatisfied than private sector employees with their social environment but that that there is no difference between them with regard to their dissatisfaction with supervision (Borges, 2013). However, previous research findings have also shown that public sector employees are more reluctant to leave their organizations compared to private sector employees, because of their greater need for job security (Baldwin, 1991; Wang, et al., 2012).

\subsection{Managing dysfunctional turnover}

Human resource practitioners have a key role to play in reducing dysfunctional turnover in organizations. They have to be actively involved in the development of well-informed human resource management policies and retention policies (Kim, 2012) and they have to assist line managers to implement these policies effectively and fairly. Job redesign, staffing tactics, training and career development initiatives, revised compensation practices as well as more effective supervisory practices could all be draw on to increase the retention of employees and to minimize costs associated with employee turnover.

Employees will experience higher levels of job satisfaction if they feel that they clearly understand their jobs. Proper selection is essential to ensure that new employees understand the nature of their jobs and that they are competent to fulfil job requirements. Clear communication should be used to establish a person-job and a personorganization fit during job interviewing (Allen, 2008). The use of explicit selection criteria would ensure that selection is vacancy specific (Van der Merwe \& Miller, 1993).

Research evidence shows that proper induction increase tenure in an organization (Kammeyer-Mueller \& Wanberg, 2003). Employees will experience higher levels of job satisfaction when any discrepancy between their expectations and reality of their jobs are clarified. Presenting applicants with a realistic job preview will therefore have a positive effect on the retention of new employees (Nel, et al., 2011).

Job satisfaction could also be managed by affecting changes in the job content environment. Jobs could be redesign to include more task significance, autonomy, task identity and task variety (Allen, 2008; Wang, et al., 2012).

Job dissatisfaction can be decreased by focusing the job context environment. The provision of competitive and fair compensation packages would go a long way in reducing dysfunctional turnover (Allen, 2008). Research findings have consistently shown that high pay and generous benefit packages reduce turnover rates (Haines, Jalette \& Larose, 2010). Flexible pay systems could be considered as an alternative to traditional pay systems to allow organizations to respond to competitive compensation packages offered by competitors (Azfar \& Danninger 2001; Blakemore, Low \& Ormiston 1987). However, performance-based pay fosters insecurity among lower level employees (Batt, Colvin \& Keefe, 2002) and this pay system is therefore not recommended as on option to reduce turnover at lower organizational levels.

Opportunities for job specific training, the development of managerial competencies as well as the use internal recruitment strategies to promote employees should be considered to decrease job dissatisfaction levels (Allen, 2008; Shore \& Griffeth, 2003; Sing, 2012). These interventions are of particular importance to motivate younger employees, females and employees in lower job positions to stay (Allen, 2008). In addition, organization should also consider the use of supportive supervision, positive feedback and rewards for accomplishments to increase the tenure of younger employees (Nel, et.al., 2011). Generous maternity leave, flexible working hours and family-friendly policies could be considered to meet the needs of female employees.

Supervisors have a key role to play in managing hygiene factors. They should be trained to manage working 
conditions in their departments effectively (Nel, et al, 2011; Shahzad et al., 2011). They should be also motivated to use a people-orientated leadership style instead of being autocratic in their interactions with their subordinates. They have to be motivated to allow for democratic decision-making and to cultivate interpersonal interaction in their units. As linking pin between management and workers they have to keep employees informed of decisions that could affect them and inform management of the concerns of employees (Allen, 2008). Two-way communication and participative decision-making are of particular importance to manage job insecurity. The findings of an extensive international review of literature on job security show that explicit, timely and open communication regarding organizational change and employee participation in decision-making about change are the most effective ways to reduce job insecurity (De Witte, 2005).

\section{Method}

\subsection{Population and Sampling}

A cross-sectional mixed method design was utilized to collect data from a public sector and a private sector organization in Limpopo Province. At the time of the study the public sector organization (Organization A) had a staff complement of 1081 employees and the private sector organization (Organization B) employed 555 staff members. A 5\% stratified sample was selected from each of the two organizations (Organization $A: n=60 ;$ Organization $B: n=30$ ).

The two samples of respondents completed a custom-made, semi-structured questionnaire. One key informant from each of the two organizations were interviewed and a focus group interview was conducted in each of the two organizations. Each of the focus groups included eight volunteers (employees on different organizational levels).

Both the organizations and all the participants were informed that their identity would be kept confidential, that the information obtained would be used for research purposes only, and that only grouped data would be reported.

\subsection{Instrumentation}

A memo was sent to all employees in the two organizations to inform them of the purpose of the study. The questionnaire that was administered contains a biographical section used to identify the age, gender and job position distributions in the two organizations, as well as open-ended and close-ended items to identify turnover drivers. Participants also expressed their opinions about the impact of employee turnover on efficiency, productivity and service delivery on a four-point Likerttype response scale, varying from very high (value $=4$ ) to very low (value $=1$ ). Questionnaires were distributed by hand and a researcher was available to clarify any misunderstandings. Questionnaires were collected immediately after completion.

A semi-structured interview was conducted with each of the two human resource managers of the two organizations to obtain their views about turnover drivers from a managerial perspective. This was followed by hour-long focus group discussion to further highlight the drivers of employee turnover in the respective organizations. Focus group interviews were utilized because they are deemed a valuable source of information to highlight the reasons why employees leave an organization (Allen, 2008; 17).

Secondary data on employee turnover rates and the financial costs to replace employees was collected from the annual reports of the two organizations. Archival data was used because at the time when the study was conducted statistics on the movement of employees were not available for the whole year.

\subsection{Data analysis}

The Statistical Package for Social Sciences (SPSS v. 21.0) was used to calculate descriptive statistics (frequency and percentage). Turnover rates were calculated by determining the ratio of the total number of leavers over the year to the average total number employed over the same period multiplied by 100 as recommended by the Chartered Institute of Personnel and Development (CIPD, 2004:2). The Chi-Square Test of independence was calculated to detect differences in turnover rates for job position, age and gender during the previous year (level of significance $=0.05$ ) in the two organizations.

The key informant interviews and focus group discussions were audio-taped and transcribed. Natural meaning units (every separate assertion expressed in words) were identified and listed for each interview item. The natural meaning units were scrutinized and clustered into dimensions of job satisfaction and job dissatisfaction that drives voluntary and involuntary employee turnover. The same data analysis process was applied to the focus group discussions. 


\section{Findings}

\subsection{Sample composition}

The gender and job position distribution in the two organizations are depicted in Table 1. It is evident from the table that both samples were balanced in terms of gender and that the majority of employees in both organizations are employed on operative levels.

Table 1. Stratified sample size based on position and gender

\begin{tabular}{|c|c|c|c|c|}
\hline \multicolumn{5}{|l|}{ Organization A } \\
\hline Position & $\begin{array}{l}\text { Population } \\
\text { frequency }\end{array}$ & $\begin{array}{c}\text { Percentage } \\
\text { required }\end{array}$ & $\begin{array}{c}\text { Respondents } \\
\text { frequency }\end{array}$ & $\begin{array}{c}\text { Proportion of } \\
\text { males to females }\end{array}$ \\
\hline Top and senior management & 13 & $1 \%$ & 2 & $1: 1$ \\
\hline Middle management & 90 & $8 \%$ & 4 & $2: 2$ \\
\hline Lower management & 254 & $23 \%$ & 14 & $7: 7$ \\
\hline Operative employees & 724 & $67 \%$ & 40 & $20: 20$ \\
\hline Total & 1081 & $100 \%$ & 60 & $30: 30$ \\
\hline \multicolumn{5}{|l|}{ Organization B } \\
\hline Position & $\begin{array}{l}\text { Population } \\
\text { frequency }\end{array}$ & $\begin{array}{c}\text { Percentage } \\
\text { required }\end{array}$ & $\begin{array}{c}\text { Respondents } \\
\text { frequency }\end{array}$ & $\begin{array}{c}\text { Proportion } \\
\text { of males to females }\end{array}$ \\
\hline Top and senior management & 1 & $0 \%$ & 0 & 0 \\
\hline Middle management & 68 & $12 \%$ & 4 & $2: 2$ \\
\hline Lower management & 192 & $35 \%$ & 10 & $5: 5$ \\
\hline Operative employees & 294 & $53 \%$ & 16 & $8: 8$ \\
\hline Total & 555 & $100 \%$ & 30 & $15: 15$ \\
\hline
\end{tabular}

\subsection{Employee turnover rates}

The overall turnover rates as well as turnover rates for different demographic groups in the target populations are represented in Table 2. The results show that the overall turnover rate in Organization A is substantially higher (23.59\%) than the overall turnover rate in Organization B (14.23\%) during the previous calendar year. The turnover rate in the public sector organization is acceptable compared turnover rates in other similar organizations in the sector (CIPD, 2004).

The turnover rates based on age, gender and job positions are also higher for all three categories in Organization A compared to the turnover rates in Organization $B$. The turnover rate for younger employees in Organization $A$ is substantially higher compared to the rate in Organization $B$, while the turnover rates for older and younger employees in Organization B are relatively similar and markedly dissimilar in Organization A. Therefore, the difference in the overall turnover rates of the two organizations is mainly attributed to a significant difference in turnover rates based on age $(p=$ 0.037).

There is no significant difference in turnover rates based on job position $(p=0.623)$ and gender $(p=0.116)$ although the turnover rates in both organizations are highest among lower management and operative employees. The rates of turnover for females in both organizations are higher that the turnover rate for males, with a very high rate of turnover of female employees (42.59\%) in Organization A.

Table 2. Employee turnover rates in previous year

\begin{tabular}{|c|l|c|c|c|}
\hline \multicolumn{5}{|c|}{ Organization A } \\
\hline \multicolumn{1}{|c|}{ Variable } & \multicolumn{1}{|c|}{ Category } & Frequency & Terminations & Turnover rate (\%) \\
\hline \multirow{4}{*}{ Position } & Top and senior management & 13 & 0 & 0.00 \\
& Middle management & 90 & 12 & 13.33 \\
& Lower management & 335 & 78 & 23.28 \\
& Operative employees & 623 & 165 & 26.48 \\
\hline \multirow{2}{*}{ Age group } & $20-39$ & 938 & 229 & 24.41 \\
& $40-$ over 69 & 143 & 26 & 18.18 \\
\hline \multirow{2}{*}{ Gender } & Male & 649 & 71 & 10.94 \\
& Female & 432 & 184 & 42.59 \\
\hline Turnover rate & & 3223 & 765 & 23.38 \\
\hline
\end{tabular}




\begin{tabular}{|c|c|c|c|c|}
\hline \multicolumn{5}{|c|}{ Organization B } \\
\hline Variable & Category & Frequency & Terminations & Turnover rate (\%) \\
\hline \multirow{4}{*}{ Position } & Top and senior management & 1 & 0 & 0.00 \\
\hline & Middle management & 68 & 2 & 2.94 \\
\hline & Lower management & 192 & 27 & 14.06 \\
\hline & Operative employees & 294 & 50 & 17.01 \\
\hline \multirow{2}{*}{ Age group } & $20-39$ & 443 & 64 & 14.45 \\
\hline & 40 -over 69 & 112 & 15 & 13.39 \\
\hline \multirow{2}{*}{ Gender } & Male & 142 & 15 & 10.56 \\
\hline & Female & 413 & 64 & 15.50 \\
\hline Turnover rate & & 1665 & 237 & 14.23 \\
\hline Job position & & & & \\
\hline Age & & & & \\
\hline
\end{tabular}

\subsection{Job satisfaction and job dissatisfaction dimensions}

The dimensions that drive turnover in the two organizations are listed in Table 3.

Table 3. Dimensions of job dissatisfaction

\begin{tabular}{|c|c|c|c|}
\hline Data source & Turnover type & Organization A & Organization B \\
\hline Questionnaire & Voluntary & $\begin{array}{l}\text { Better job offers elsewhere } \\
\text { Poor compensation } \\
\text { Poor working conditions } \\
\text { Lack of promotion opportunities } \\
\text { Autocratic supervisor management style } \\
\text { Poor interpersonal relationships }\end{array}$ & $\begin{array}{l}\text { Better job offers elsewhere } \\
\text { Non-competitive compensation } \\
\text { Lack of promotion opportunities }\end{array}$ \\
\hline Interview & Voluntary & $\begin{array}{l}\text { Better job offers elsewhere } \\
\text { Lack of promotion opportunities }\end{array}$ & $\begin{array}{l}\text { Better job offers elsewhere } \\
\text { Lack of promotion opportunities }\end{array}$ \\
\hline Focus Group & Voluntary & $\begin{array}{l}\text { Better job offers elsewhere } \\
\text { Poor compensation } \\
\text { Poor working conditions } \\
\text { Lack of promotion opportunities } \\
\text { Poor interpersonal relationships } \\
\text { Autocratic supervisor management style }\end{array}$ & $\begin{array}{l}\text { Better job offers elsewhere } \\
\text { Non-competitive compensation } \\
\text { Lack of promotion opportunities }\end{array}$ \\
\hline
\end{tabular}

The results indicate that only hygiene factors were identified by respondents. Participants from Organization A identified more drivers of voluntary turnover compared to participants in Organization B. Better job offers elsewhere appear to be the main factor that drives voluntary turnover in both organizations. Most participants also identified compensation issues and a lack of promotional opportunities as factors that contribute to voluntary turnover.

\subsection{Impact of employee turnover}

The average costs to recruit employees for different position are given in Table 4. It is evident from Table 4 that there is a significant difference in the recruitment costs of the two organizations $(p=0.00)$. The costs to recruitment top, senior and middle level managers are slightly higher for Organization B compared to the costs in Organization A. On the other hand, the costs of recruiting employees for lower management positions is higher for Organization $A$ and the recruitment of operative level employees unexpectedly low for Organization B, compared to the costs incurred by Organization A.

Table 4. Employee replacement costs

\begin{tabular}{|c|c|c|}
\hline Position & Organization A: Average personnel cost & Organization B: Average personnel cost \\
\hline Top \& senior management & R447 000 & R500 000 \\
\hline Middle management & R273 000 & R300 000 \\
\hline Lower management & R209 000 & R150 000 \\
\hline Operative employees & R192000 & R60 000 \\
\hline Total & R1121 000 & R1010 000 \\
\hline
\end{tabular}

$$
p=0.00^{*}
$$


Questionnaire respondents' responses with regard to the impact of employee turnover are shown in Table 5. It would appear that overall there in a significant difference in the perception of employees in the two organization with regard to the impact of turnover on efficiency, productivity and service delivery $(p=0.03)$. Most of the respondents indicated that turnover has a high impact on the functioning of their respective organizations.

Table 5: Perceived impact of employee turnover

\begin{tabular}{c|c|c|c|}
\hline \multicolumn{3}{|c|}{ Organization A } \\
\hline Impact & Frequency & Percentage of respondents (\%) \\
\hline High & 49 & 81.7 \\
\hline Low & 11 & 18.3 \\
\hline Total & 60 & 100.0 \\
\hline \multicolumn{2}{|c|}{} \\
\hline Impact & Frequency & Organization B \\
\hline High & 18 & Percentage of respondents (\%) \\
\hline Low & 12 & 60.0 \\
\cline { 2 - 3 } & Total & 30 & 10.0 \\
\cline { 2 - 3 } \\
\cline { 2 - 3 }
\end{tabular}

\section{Discussion and Conclusion}

The findings of the study provide empirical evidence that both the public and private organizations in Limpopo Province have to compete for human resources with their counterparts in other parts of the country. The main factor that contributed to dysfunctional employee turnover in the two organizations is the availability of more lucrative job opportunities in other parts of the country. Both organizations will have to revise their compensation practices to become more competitive. They should consider innovative reward systems to recognize the contributions of employees in instances where their compensation policies cannot be changed. The provision of career advancement opportunities, for example, the use of internal recruitment to promote employees could be also employed to decrease their levels of job dissatisfaction and to motivate them to stay.

Furthermore, it would appear that the public sector organization has a greater turnover problem compared to the private sector organization. Although dysfunctional employee turnover has a negative impact on the efficiency, productivity and service delivery of both organizations, the impact is more severe in the public sector organization. The costs of replacing lower level employees are also much higher in the public sector organization.

The turnover rate for employees in the public sector organization is substantially higher compared to the turnover rate of employees in the private sector organization. As previously mentioned in this article, demographic factors contribute to employee turnover. The difference in the turnover rates of the two organizations is mainly attributed to the high turnover rate of younger employees in the public sector organization. Initiatives to retain younger employees (i.e., vacancy specific selection, proper induction, job specific skills development, recognition, and supervisory support) should be considered to reduce dysfunctional turnover.

The high turnover rate for female employees in the public sector organization as well as employees on lower management and operative levels in both organizations should be investigated further to identify their specific needs and to determine what factors drive them to resign. Strategies could then be developed to decrease their turnover to an acceptable level, for example they should be provided with opportunities for promotion and advancement.

The findings of the study show that the public sector employees are dissatisfied with more hygiene factors compared to the employees in the private sector. The higher turnover rate in the public sector organization could therefore also be attributed to employees' dissatisfaction with working conditions, supervision and interpersonal relationships. Supervisory training should be a priority in the public sector organization. Supervisors should be motivated to adopt a people-orientated leadership style, to manage working conditions effectively, to enhance interpersonal communication and engaging in relationship building in their respective units. They should also support their subordinates and ensure open and transparent communication between themselves, their subordinates and management.

Research findings have consistently shown that both job dissatisfaction and job satisfaction are drivers that contribute to dysfunctional employee turnover (Griffith, Horn \& Gaertner, 2000; Horn \& Kinicki, 2001; Shahzad, Hayat, Abbass \& Bashir, 2011; Shields \& Ward 2001; Yücel, 2012). However, in the present study respondents only identified job dissatisfaction as a driver of employee turnover. It would thus appear that job satisfaction is not an issue in the two 
organizations under investigation. It is recommended that annual survey should be conducted in both organizations to determine if there are changes in the job satisfaction and job dissatisfaction of employees over time. In addition, this will provide evidence of the effectiveness of retention practices.

The present study is limited in scope and more research needed before the findings could be generalized to other organizations in the region. Furthermore, previous research findings show that that the job satisfaction of workers differs from geographical region to geographical region in a country (Ghinetti, 2007). It is recommended that research should be conducted to compare turnover rates as well as the satisfaction and dissatisfaction of employees between regions in South Africa.

\section{References}

Allen, D.G. (2008). Retaining talent: a guide to analysing and managing employee turnover. USA: SHRM Foundation.

Allen, D. G., Shore, L. M. \& Griffeth, R. W. (2003). The role of perceived organizational support and supportive human resource practices in the turnover process. Journal of Management, 29 (1), 99-118.

Azfar, O. \& Danninger, S. (2001). Profit-sharing, employment stability, and wage growth. Industrial and Labor Relations Review, 54 (3): $619-630$

Baldwin, J.N. (1991). Public versus private employees: debunking stereotypes. Review of Public Personnel Administration, 11(1-2): 1-27.

Ballester, M. B., Livnat, J. \& Sinha, N. (2012). Labor costs and investments in human capital. Journal of Accounting, Auditing and Finance, 17(4): 351-373.

Bordia, P. \& Blau, G. (1998). Pay referent comparison and pay level satisfaction in private versus public sector

organizations in India. The International Journal of Human Resource Management, 9:1: 155-167.

Borges, R. (2013). Are public officials really less satisfied that private sector workers? A comparative study Brazil. Revista Brasileira de Administração Pública, 47 (6): 1477-1496.

Batt, A., Colvin , J .S. \& Keefe, J. (20020. Employee voice, human resource practices, and quit rates: Evidence from the telecommunications industry. Industrial and Labor Relations Review, 55 (4): 573-94.

Buelens, M. \& Van den Broeck, H. (2007). An analysis of differences in work motivation between public and private sector organizations. Public Administration Review. 67 (1): 65-74.

Chen, L. (2008). Job satisfaction among information system (IS) personnel. Computers in Human Behavior, 24: $105-118$.

Choi, S. L. \& Lee, Y. T. (2011). Relationship between leadership style, job satisfaction and employees' turnover intentions: a literature review. Research Journal of Business Management, 5 (3): 91-100.

Choi, S. L., Musibau, A. A., Khalil, M. N. \& Ebi, S. S. (2012). The approaches to increase employees' loyalty: a review on employees' turnover models. Australian Journal of Basic \& Applied Science, 6 (10): 282-291.

CIPD. (2004). Employee turnover and retention. London: CIPD.

De Witte, H. (2005). Job security: review of the international literature on definitions, prevalence, antecedents and consequences. SA Journal of Industrial Psychology, 31 (4): 1-6.

Ghinetti, P. (2007). The public-private job satisfaction differential in Italy. Review of Labour Economics \& Industrial Relations, 21 (2): 361-388.

Griffith, R. W., Hom, P. W. \& Gaertner, S. (2000). A meta-analysis of antecedents and correlates of employee turnover: update, moderator tests, and research implications for the next millennium. Journal of Management, 26 (3), 463-488.

Gupta, R. (2011). Salary and satisfaction: public-private sectors in J \& K. SCMS Journal of Indian Management, October - December: 71-77.

Haines, V. Y., Jalette, P. \& Larose, K. (2010). The influence of human resource management practices on employee voluntary turnover rates in the Canadian non-governmental sector. Industrial and Labor Relations Review, 63 (2): 228-246.

Herzberg, F. (1968). One more time. How do you motivate employees? Harvard Business Review, 46 (1): 53-62.

Herzberg, F., Mausner, B. \& Snyderman, B. B. (1959). The Motivation to Work (2nd ed.). New York: John Wiley.

Hom, P. \& Kinicki, A. J. (2001). Toward a greater understanding of how dissatisfaction drives employee turnover. Academy of Management Journal, 44(5): 975-987.

Houston, D. J. (2000). Public service motivation: a multivariate test. Journal of Public Administration Research and Theory. 10 (4): 713 27.

Ito, J. K. (2003). Career mobility and branding in the civil service: an empirical study. Public Personnel Management, 32 (1):1-21.

Kabungaidze, T., Mahlatshana, N. \& Ngirande, H. (2013). The impact of job satisfaction and some demographic variables on employee turnover intentions. International Journal of Business Administration, 4 (1): 53-65.

Kammeyer-Mueller, J.D. \& Wanberg, C.R. (2003). Unwrapping the organizational entry process: Disentangling multiple antecedents and their pathways to adjustment. Journal of Applied Psychology, 88: 779-794.

Kellough, J. E. \& Haoran, L. (1993). The paradox of merit pay in the public sector: Persistence of a problematic procedure. Review of Public Personnel Administration, 13 (2):45-64.

Kasimati, M. (2011). Job satisfaction and turnover under the effect of person-organization fit in Albanian public organizations. Journal for East European Management Studies. 16 (4): 315-337.

Kim, S. (2012). The impact of human resource management on state government IT employee turnover intentions. Public Personnel 
Management, 41 (2): 257-279.

Liu, D., Mitchell, T. R., Lee, T. W., Holtom, B. C. \& Hinkin, T. R. (2012). When employees are out of step with co-workers: how job satisfaction trajectory and dispersion influence individual - and unit-level voluntary turnover. Academy of Management Journal, 55 (6): 1360-1380.

Lynch, J. \& Tuckey, M. (2008). The police turnover problem: Fact or fiction. International Journal of Police Strategies and Management, 31 (1): 6-18.

Macklin, D. S., Smith, L. A. \& Dollard, M. F. (2006). Public and private sector work stress: workers compensation, levels of distress and job satisfaction, and the demand-control-support model. Australian Journal of Psychology, 58 (3): 130 - 143.

Maidani, E. A. (1991). Comparative study of Herzberg's two-factor theory of job satisfaction among public and private sectors. Public Personnel Management. 20 (4): $441-48$.

Meier, K. J. \& Hicklin, A. (2008). Employee turnover and organizational performance: Testing hypothesis from classic public administration. Journal of Public Administration Research, 18 (4): 573-590.

Miceli, M. P. \& Mulvey, P. E. (2000). Consequences of satisfaction with pay system: Two Field studies. Industrial Relations, 39: $62-87$.

Nel, P. S., Van Dyk, P. S., Haasbroek, G .D., Schultz, H. B., Sono, T. \& Werner, A. (2011). Human resources management. (8 $8^{\text {th }}$ Ed). Southern Africa: Oxford University Press.

Oosthuizen, M \& Naidoo, P. (2004). Internal migration to the Gauteng Province. Development Policy Research Unit, December 2004.Working Paper 04/88. [online] Available:

http://www.queensu.ca/samp/migrationresources/Documents/Oosthuizen_internal.pdf

Radebe, S. (2009). A task that's achievable. [online] Available:

http://free.financialmail.co.za/report09/trade09/btrade.htm

Rainey, H. G. \& Bozeman, B. (2000). Comparing public and private organizations: empirical research

and the power of a priori. Journal of Public Administration Research and Theory, 10 (2): 447-470.

Schneider, D. S. \& Vaught, B. C. (1993). A comparison of job satisfaction between public and private sector managers. Public administrative Quarterly, 17 (1): 68-83.

Shahzad, K., Hayat, K. , Abbass, M. \& Bashir. S. (2011). Antecedents of turnover and absenteeism: evidence from public sector institutions of Pakistan. Interdisciplinary Journal of Contemporary Research in Business, 2 (9): 108-120.

Shields, M. A. \& Ward, M. E. (2001) Improving nursing retention in the British national health service: the impact of job satisfaction on the intentions to quit. Journal of Health Economics, 20: 677-701.

Sing, D. (2012). Human resource challenges confronting the senior management service of the South African public service. Public Personnel Management, 41 (2): 379-388.

Sulaiman O. A. \& Ogunsina, S. O. (2011). Influence of supervisory behaviour and job stress on job satisfaction and turnover intention of police personnel in Ekiti State. Journal of Management and Strategy, 2 (3): 13-20.

Van der Merwe, R. \& Miller, S. (1988). Measuring absence and labour turnover: a practical guide to recording and control. Johannesburg: Lexicon.

Waldman, J. D., Kelly, F., Arora, S. \& Smith, H. L. (2004). The shocking cost of turnover in health care. Health Care Management Review, 29 (1): 2-7.

Walsh, K. \& Tayor, M. S. (2007). Developing in-house careers and retaining management talent what hospitality professionals want from their jobs. Cornell Hospitality Quarterly, 48 (2), 163-182.

Wang, Y., Yang, C. \& Wang, K. (2012). Comparing public and private employees job satisfaction and turnover. Public Personnel Management 41 (3): 557-573.

Wright, B. E. \& Kim, S. (2004). Participation's influence on job satisfaction. Review of Public Personnel Administration, 24:18-40.

Yücel, I. (2012). Examining the relationships among job satisfaction, organizational commitment, and turnover intention: an empirical study. International Journal of Business and Management, 7 (20): 41-58. 